\title{
The Analysis of South African Economic Situation
}

\author{
Qiaochu Liu ${ }^{1, \dagger}$ Jiawei Sun ${ }^{2, *}, \dagger$ Ting Zhang ${ }^{3, \dagger}$ \\ ${ }^{1}$ Philosophy, Religion and History of Science, University of Leeds, Leeds, UK \\ ${ }^{2}$ Rutgers University Newark Institute at Northeast Normal University, Changchun, China \\ ${ }^{3}$ School of Social and Political Science Sciences, University of Glasgow, Glasgow, UK \\ ${ }^{*}$ Corresponding author. Email: ${ }^{2}$ pr19ql@leeds.ac.uk
}

These authors contributed equally.

\begin{abstract}
This review will focus on what social development looks like under the influence of South African economic policy. In particular, it will focus on implementing and developing the "Black Economic Empowerment Policy". At the same time, specific charts and data will be provided to support the views of the Review. At present, specific studies have classified the different states under the influence of South Africa's economic policies, but there are still some omissions on the subsequent improvement. This review will comb through the research in the policy area, with contributing to future research.
\end{abstract}

Keywords: Black Economic Empowerment policy, Improvement, Revolution, Reaction

\section{INTRODUCTION}

On July 7, 2021, former South African President Zuma was sentenced to 15 months in prison for "contempt of court". The incident immediately triggered protests by Zuma's supporters in many parts of South Africa. Still, the protests soon turned into large-scale violent riots and caused a large number of casualties and economic losses. The normal social order in South Africa was also seriously affected. On the surface, the incident was triggered because of the political struggle. However, after the shell was peeled off, the root cause of the matter was the existence of the "black and white binary economy", which brought about a serious gap between the rich and the poor and social inequality in South Africa.

The "BEE deal" is precisely a targeted policy of the South African government to support the "historically disadvantaged South Africans" to pacify the lower strata of society and stabilize the social order. "Since its implementation, the BEE deal has had a certain degree of positive impact on the socioeconomic development of South Africa, and it has also been controversial for various reasons.

In view of the importance of the BEE deal in the implementation of South Africa's "black economic revitalization" and its key role in promoting the development of the black economy in South Africa, it is necessary to conduct an in-depth study and analysis of this policy.

At present, the academic research on Black Economic Empowerment (BEE) policy is more focused on broadbased black economic empowerment (B-BBEE) policy, which was formally implemented after being deliberated and passed by Congress in 2003. The B-BBEE policy is based on the BEE policy and aims to further correct South Africa's economy in a unified but diverse way. That would give disadvantaged blacks more economic rights. The academic circle mainly analyses the effects of BEE policy in certain effects of BEE policy in different fields such as tax laws, economic law and other legal aspects of B-BBEE policy to put forward relevant suggestions for improvement. In addition, it also expresses some existing problems and solutions. All these papers talk about how more can be done to make the black economy more vitality. At the same time, it also provides effective suggestions for the development of BEE policy so that BEE policy can keep pace with the times and better promote the development of South Africa. Compared with the past, the academic circle has paid more attention to analysing the impact of black economic policies. The BEE policy permeates every aspect of South Africa's economic development. It still plays a very powerful role, but it needs to be improved with the development of society.

So, in the last part, this review will also elaborate on some more summary content. Therefore, this review will 
first focus on the social context (both economic and political) of implementing the "BEE" economic policy in South Africa. It is easy to see that some specific social backgrounds are the prerequisites for the birth of some policies. South Africa, for example, is in dire need of radical change after the end of apartheid, as it already poses a threat to the peace and development of the whole country when economic inequality falls between races. This is both an opportunity and a driving force for the birth of the BEE policy. After sorting out, this review will conclude the consensus conclusion in a comprehensive way, but there are also opposing opinions and voices. At the same time, the review will summarize the detailed measures and impacts of the "BEE" policy. Given that the BEE policy has been altered in many different ways, covering almost all of South Africa's recent economic history, its impact should not be limited to just one aspect. Even each angle should be differentiated and refined. Absolutely, the review also believes that this policy is not perfect. It must be overlooked in some parts. However, this is not what this review will discuss specifically in this review. The review will outline it but will explore and mention it in future reviews.

\section{THE REVIEW OF BLACK ECONOMIC EMPOWERMENT POLICY IN TERMS OF BACKGROUNDS}

There are relatively few studies on the background of black economic revitalization policies. Generally speaking, scholars focus on the view that BEE policy is put forward to meet political and economic development needs. There are two reasons why the policy of black revitalization is mainly focused on political and economic factors. On the political side, it was mainly the election of the African National Congress and the coming to power of Nelson Mandela that abolished the apartheid policy. On the economic side, it was the overcoming of the legacy of the apartheid policy and the avoidance of the phenomenon of black South Africans being excluded from and confined to the periphery of the national economy.

\subsection{Related Research on Political Factors}

There are relatively few studies on the background of black economic revitalization policies. Generally speaking, scholars focus on the view that BEE policy is put forward to meet political and economic development needs. There are two reasons why the policy of black revitalization is mainly focused on political and economic factors. On the political side, it was mainly the election of the African National Congress and the coming to power of Nelson Mandela that abolished the apartheid policy. On the economic side, it was the overcoming of the legacy of the apartheid policy and the avoidance of the phenomenon of black South Africans being excluded from and confined to the periphery of the national economy.

\subsubsection{The Abolition of Apartheid}

The abolish of Apartheid is one of the reasons for developing Black Economic Empowerment. In history, South Africa was invaded successively by the Netherlands and the United Kingdom and was colonized for a long time. The establishment of the Republic of South Africa in 1960 was a major event on the African continent at that time. However, the newly established Republic of South Africa was still governed by white people and continued to implement the policies of apartheid and racial discrimination [1].

Apartheid mainly segregated people into whites, blacks, Indians, and other colored people. The white community, which controlled the country's economic and social system, faced a dilemma: they expected black people to create prosperity for the society, but they also feared integrating black and white people in a common society. They imposed a geographical separation of South Africa's ethnic group to solve the problem, creating "black homelands" [2]. Seen from the outside, these homelands are like autonomous nations. However, they have to be run by chiefs appointed by the white government. They no longer have the citizenship of the Republic of South Africa and are exploited by whites. Apartheid entrenched racial and gender discrimination and threatened almost every aspect of the social, economic, and political elite. Under apartheid, whites were given priority over blacks in ownership of land, business assets, education, and amenities [3].

According to Luiz, in 1955, about 58\% of South Africans and $68 \%$ of African South Africans lived in poverty, and South Africa's Gini coefficient was 0.56 . He added that the country is facing a shortage of skilled Labour and excess less skilled or unskilled workers, Apartheid wage gap, namely the highest income ratio between executives and the lowest-income workers, is too high, the labor market discrimination, work to reserve, for example, and the past doesn't equal education and training opportunities, make sure the white than black discriminatory advantage [4]. Under nearly half a century of Apartheid, most black South Africans were either excluded or confined to the margin of the country's mainstream economy. As a result, it cannot make corresponding contributions to the economic development of South Africa, and to a certain extent, it greatly restricts the economic development of South Africa. Due to the implementation of the apartheid, black social rights are limited, no chance to get the corresponding education opportunities to improve their skills, relying only on a few white to South Africa's economic development is very slow and easy to create class curing, is not conducive to form a benign competition environment, stimulate the potential of 
South Africa's economy. To a certain extent, the further development of South Africa's economy has been restrained. Abolish Apartheid would have been better for the economy.

\subsubsection{Mandela Comes to Power}

Mandela became president of South Africa is another reason. Ponte, Robert, and Sittert pointed out that Mandela proposed to devolve power from the hands of white capitalists to the black apartheid system. Black businesses were limited to the activities of black people, and different regulations widened the economic gap between different black groups under the apartheid system [5] after Mandela became president of South Africa. "Black economic empowerment" is one of the major measures to support the development of the black economy during the Mandela period of South Africa. The main contents include: implementing priority procurement, formulating commercial licenses and quotas, promoting the reorganization and privatization of state-owned enterprises and establishing a public-private partnership. From the perspective of balanced ethnic, economic development," black economic revitalization "can help to support" historically disadvantaged South Africans". Some positive results have been achieved.

\subsubsection{The Rise of Black People's Political Status}

The rise of Black people's political status is the reason for developing BEE policy as well. Southhall mentioned that since coming to power in 1994, South Africa's African People's National Congress (ANC) government has sought to address the power imbalance between the country's white minority and its black population [6]. In 1994, the black government was established, and South Africa moved from apartheid to democracy. The improvement of black people's political status also required the change of their social and economic status. One of the main objectives of the post-apartheid government was to redress the imbalances in socioeconomic development resulting from apartheid. To this end, the South African government began to implement the "Reconstruction and Development Plan", which aims to promote sustainable economic development through "redistribution". The BEE policy is at the heart of South Africa's reconstruction and development program. However, in the decades before South Africa achieved democracy in 1994, the apartheid government systematically excluded Africa, India and colored people from meaningful participation in the country's economy.

\subsection{Related Research on Economic Factors}

Southhall mentioned that 350 years of white supremacy had deprived Africans and people of color of the possibility of independent economic survival, severely limited commercial opportunities among Indians geographically and socially and turned blacks as a whole into suppliers of labor in the face [6]. For the further development of South Africa, the government have to support the development of black people since one country may not be prosperous only rely on a few parts of citizens. The development of a country does not depend on a small number of rich people but, on the whole, a standard of living. Most of the whites have a good level of education and grasp a large number of advanced technology. In contrast, the blacks generally have a low level of education and cannot make a living and learn to keep pace with The Times. In this case, the long-term development of the country will be affected. Only a collective with a sense of competition can develop well. If the class of a country is severely solidified, the white people's sense of crisis will be weak, and the prevailing hedonism will often be out of touch with the world. They will no longer learn advanced technology and cannot develop at the national level. Thus, the whole country will be in a backward and poor situation. Therefore, promoting the development of black is extremely crucial, not only for economic but also important for racial equity. Black economic empowerment is not simply a moral imperative to redress the inhuman policies of apartheid. It is a pragmatic growth strategy to realize its full potential by bringing the black majority into the economic mainstream.

Although there are many contributing factors, scholars mainly start from the political and economic aspects. BEE policy plays an important role in South Africa's development, whether from the unfair political oppression or the economic restriction.

\section{THE REVIEW OF BEE MEASURES}

Through in-depth study of the literature involving measures of BBE, it can be found that some scholars focused on a certain stage of the BBE policy. For instance, some only studied the BBE policy during the Mandela period. Some focused on the analysis of the B-BBEE; some focused on holistic research and conducted a systematic analysis of the entire historical evolution of the BBE. Although some scholars focused on analyzing the impact of the BBE policy, the article also analyzed the specific measures of BEE.

During the white South African government (19101994), apartheid and racial discrimination policies were implemented. Blacks were excluded from the mainstream economy. The existence of the "black and white dual economy" brought a severe wealth gap and social inequality to South Africa. Relying solely on civil, social, and personal power cannot achieve a fundamental reversal of the black economy. After establishing New South Africa in 1994, the African National Congress (ANC) embarked on Black Economic Empowerment (BEE) as a project of redistribution of productive 
resources to the benefit of groups previously disadvantaged by the system of apartheid [7]. The Constitution of the Republic of South Africa Act 108 of 1996 allows the government to introduce legislative policy designed to advance previously disadvantaged groups, which laid a legal basis for the government to implement BEE. Because of its complexity, BEE is not easy to define. As Kleynhans, E.P.J. \& Kruger, M.C. explains, "There is a risk of defining it too broadly, creating the idea that BEE is only focused on economic development and transformation in general. On the other hand, the risk might be a too narrow definition, creating the false idea that BEE is only about transferring ownership of corporate assets from white people to black people" [8]. At the same time, because the BEE policy is also undergoing continuous development and evolution, showing different characteristics at different stages and taking different measures, it is impossible to generalize the BEE policy. Based on the above considerations, we distinguish between two phases of $\mathrm{BEE}$ for more objective research and analysis.

\subsection{Related Research on The Early BEE (1994- 2000)}

In the second half of the 1990s, Ponte, S., Roberts, S., \& van Sittert, L. note, "BEE was characterized by ownership deals that took place while legislation (not specifically referred to as 'empowerment' legislation) was enacted to address issues of employment equity, labor rights and skills development, but in the absence of an over-arching framework" [9]. Acemoglu, D., Gelb, S. \& Robinson J.A. write, "BEE was aimed at correcting the imbalances of the past and working toward a transfer of ownership of financial resources to black people, which was the initial focus on BEE" [10]. In May 1998, the South African government established the BEE Commission to strengthen the unified guidance of the BEE policy, which is subordinate to the Department of Trade and Industry (DTI). ANC has also formulated a series of legislative measures to provide new economic opportunities for the black community. In 1996, The Employment Equity Act originated as a Green Paper on Employment Equity. This Green Paper encouraged organizations to audit their organizational structures and develop equity plans, which ultimately came into existence in the Employment Equity Act 55 of 1998 [11]. The Skills Development Act of 1998 aimed to empower the workforce with skills, ensure the black access more work opportunities [12]. The Preferential Procurement Policy framework Act of 2000 implemented the constitution's requirements to protect disadvantaged groups by clarifying preferential procurement policy [13]. On the whole, as HuangYupei explains, "At this stage (1994-2000) the government mainly adopted Preferential Procurement, Business Licenses and Quotas, Restructuring and Privatization of StateOwned Enterprise and Public-Private Partnership to promote "Black Economic Empowerment" [14].

Despite these measures, the effectiveness of the BBE policy was not obvious. The beneficiaries are limited to black individuals rather than groups. Some blacks with political sensitivity and business intelligence quickly became rich. Still, the majority of the black poor at the bottom of society did not enjoy the support of the policy. Sharma, R.compares the impact of the BEE strategy to "white cream over a large black mass, with some chocolate sprinkled on top" [15]. In addition, it exacerbated the polarization between the rich and the poor. Not only because "the government lacked a coherent overall strategy for BEE", as Hirsch writes [16], but also the government did not take direct sanctions or levers to achieve governmental goals. Ponte, S., Roberts, S., \& van Sittert, L. notes, "The government rapidly moved away from the developmental and somewhat interventionist approach set out in the RDP to concerns with ensuring that government policies did not harm'business confidence were perceived as 'marketfriendly" [17].

\subsection{Related Research from $B E E$ to $B-B B E E$ (After 2000)}

After digesting and absorbing the advantages and disadvantages of the early BEE, a Broad-Based BEE Act and associated codes were promulgated in 2000. The early empowerment charters were the first industryspecific initiatives that embedded this approach. For instance, the Petroleum and Liquid Fuels Charter presented a strategy for increasing the involvement of 'Historically Disadvantaged South Africans' (HDSA) [18]. The Mining Charter [19] stipulated mining companies achieving 26 per cent HDSA ownership of the mining industry assets in ten years.

Burger, R. \& Jafta, R. note, "During 2003, the outline of the concept of broad-based black economic empowerment (B-BBEE) came into existence by means of a policy published by the DTI. The Broad-Based Black Economic Empowerment Act 53 of 2003 was assented to on 07 January 2004" [20]. This Act further states that BEE means the economic empowerment of Blacks, including women, workers, youth, disabled, and people are living in rural areas, through diverse but integrated socio-economic strategies. The government's stated objectives are to facilitate the empowerment of Blacks [21]:

1) Promoting economic transformation to enable meaningful participation of Blacks in the economy.

2) Achieve change in the racial composition of ownership and management structures and in skilled occupations of existing and new businesses. 
3) Increasing the extent to which black women own and manage existing and new businesses and increasing their access to economic activities, infrastructure, and skills training.

4) Increasing the extent to which communities, workers, co-operatives, and other collective businesses own and manage existing and new businesses and increasing their access to economic activities, infrastructure, and skills training.

5) Promoting investment programs that lead to BEE and meaningful participation in the economy by Blacks to achieve sustainable development and prosperity.

6) Empowering rural and local communities by enabling them access to economic activities, land, infrastructure, ownership, and skills.

7) Promoting access to BEE financing and funding.

Burger, R. \& Jafta, R. show that Codes of Good Practice were then developed and published by the Ministry on 09 February 2007 [22]. As Kruger, L.P. explains, "It was acted as a guideline for the overall operational aspects of the BEE strategy in South Africa" [23]. The Codes of Good Practice for BEE comprise about 96 pages and provide detailed explanations of the framework and measurement of ownership, including numerous mathematical formulate for calculating the seven individual elements (Table 1) [24]. In terms of the generic scorecard, a company's level of compliance with the seven individual elements determines its B-BBEE status (Table 2) [25]. Tucker writes, "The goal of this evaluation lies in the fact that the score obtained can be used to enhance a BEE enterprise's relationship with government entities in terms of procurement, the establishment of public-private relationships, purchase of state-owned enterprises and any other relevant economic activity" [26].

Table1. Elements and weightings of the generic BBBEE scorecard) [25]

\begin{tabular}{lll}
\hline Element & Weighting & $\begin{array}{l}\text { Code series } \\
\text { reference }\end{array}$ \\
\hline Ownership & 20 points & 100 \\
Management control & 10 points & 200 \\
Employment equity & 15 points & 300 \\
Skills development & 15 points & 400 \\
Preferential & 20 points & 500 \\
procurement & & \\
Enterprise & 15 points & 600 \\
development & & \\
Socioeconomic & 5 points & 700 \\
development initiatives & & \\
\hline
\end{tabular}

Table2. B-BBEE status, qualification and recognition level [26]

\begin{tabular}{|c|c|c|}
\hline B-BBEE Status & Qualification & $\begin{array}{l}\text { B-BBEE } \\
\text { recognition level } \\
\text { (Percentage) }\end{array}$ \\
\hline Level One & $\geq 100$ points on the & 135 \\
\hline \multirow[t]{2}{*}{ Contributor } & Generic & \\
\hline & Scoreboard & \\
\hline Level Two & $\geq 85$ but $<100$ on & 125 \\
\hline \multirow[t]{2}{*}{ Contributor } & the Generic & \\
\hline & Scoreboard & \\
\hline Level Three & $\geq 75$ but $<85$ on the & 110 \\
\hline \multirow[t]{2}{*}{ Contributor } & Generic & \\
\hline & Scoreboard & \\
\hline Level Four & $\geq 65$ but $<75$ on the & 100 \\
\hline \multirow[t]{2}{*}{ Contributor } & Generic & \\
\hline & Scoreboard & \\
\hline Non-compliant & $<30$ on the Generic & 0 \\
\hline Contributor & Scoreboard & \\
\hline Level Five & $\geq 55$ but $<65$ on the & 80 \\
\hline \multirow[t]{2}{*}{ Contributor } & Generic & \\
\hline & Scoreboard & \\
\hline Level Six & $\geq 45$ but $<55$ on & 60 \\
\hline \multirow[t]{2}{*}{ Contributor } & the Generic & \\
\hline & Scoreboard & \\
\hline Level Seven & $\geq 40$ but $<45$ on & 50 \\
\hline \multirow[t]{2}{*}{ Contributor } & the Generic & \\
\hline & Scoreboard & \\
\hline Level Eight & $\geq 30$ but $<40$ on & 10 \\
\hline \multirow[t]{2}{*}{ Contributor } & the Generic & \\
\hline & Scoreboard & \\
\hline Non-compliant & $<30$ on the Generic & 0 \\
\hline Contributor & Scoreboard & \\
\hline
\end{tabular}

In a few words, B-BBEE is a deep interpretation of the early BEE. It is a process that the government has continuously introduced effective measures based on the South African economic situation. In this way, the supervision of carrying out the BBE policy in various industries is strengthened, and the speed of national economic development is gradually accelerating.

\section{CONSENSUS SUMMARY}

In the third stage, this review will be inclined to make some summary of the previous work. The first is the summary of the research content. Throughout the review, it has been paying attention to the academic perspective on the "BEE" policy and the cross-disciplinary research. As an economic policy, the "BEE" policy was intended to revitalize the South African economy by supporting the black economy. But it covers too many ideological clashes with politics and culture. Just like the view 
showed in the Inequality in South Africa during and since Apartheid, after the end of apartheid, the government tried to "racially compensate" the blacks who had been exploited. Insisting that all political parties have a longterm interest in tackling unemployment and bringing the marginalized poor into the economic, social and political system [27].

As mentioned in a recent review, South African apartheid is the only reactionary system in the world today. Under this cruel system, black South Africans were colonized by a minority of whites and subjected to racial discrimination [28]. In this case, the promotion of the "BEE" policy is economic support for black people and a guarantee for the promotion of black people's political status. Therefore, at the social level, the emergence of "BEE" policy is not only economic support should be accepted by most people. It raised the racial status of blacks and also tried to balance racial discrimination between blacks and whites. This is a significant change in the status of black people who used to have a lower status in the international community. The "BEE" policy gave black people many opportunities to earn their own living on the economic side. Under the influence of the apartheid policy, most blacks did not receive a good education, so they could not compete with whites in many sectors. But through BEE, along with the requirement for black employment, political and economic favors were given to blacks, giving them access to the central leadership and predominantly white businesses. Blacks no longer have to rely heavily on whites to make a living, as they did under apartheid. This was a good chance for the later development of the black race as a whole.

To sum up, rather than just economic reform, this review thinks South Africa's "BEE" policy can be seen as a global humanitarian affirmation of the rising status of black people. Whether it was due to the huge economic losses caused by the divestment campaign launched by the United States in 1986, or the sense of crisis that the country was on the brink of civil war due to the intensification of internal racial conflicts, the emergence of the "BEE" policy allowed the South African government to take a break and tackle the issues. Therefore, this review agrees with the evaluation of the "BEE" policy in this article. The emergence of the BEE policy improved the economic imbalance in South Africa to a certain extent and continuously promoted the economic and political status of black people in the country [29].

\subsection{Research Review on Disadvantage}

\subsubsection{Double-Edged Sword}

But one coin has two sides. The "BEE" policy is a policy plan used by the South African government for emergency relief in a short period of time, so there are still many serious loopholes to be filled in the setting.
Like the point in Not Separate, Not Equal: Poverty and Inequality in Post-Apartheid South Africa, although apartheid was cruel, it also brought about some cultural and ideological changes [30]. Maybe on some level, apartheid just played a role to trigger the economics. So, on the other side, a lot of reviews show limitations. BEE policy is not all the right aspects. The failure of the BEE policy is that the new change and the disharmonious relationship with the former led to a weak policy with a bad ending [31]. After the end of apartheid, security conditions in South Africa began to deteriorate rapidly, and the low-quality population flooded the cities. Key sectors that used to be dominated by whites are now unable to find the right people of high quality. Even under Mandela's policy of forcing businesses to hire black people on a certain scale, South Africa suffered from an abysmal economic unemployment rate.

\subsubsection{Talent Shock}

Even more, along the way to change, they run into a different sort of corrected inequality. The government quickly reshuffled public offices, failing personnel selection and rapid corruption of South Africa's public service system to cut off white control. White people can't get good jobs even if they have the ability because of their race. The shock of the exodus of whites from South Africa in large numbers in the 1980s was huge. Economically, companies were forced to accept black workers on a proportional basis. They took advantage of the "BEE" policy and became lazy, unwilling to learn and unwilling to produce. The equality policy imposed by the government has not really benefited South Africa much. Instead, it has suffered a brain drain. South Africa's overreliance on minerals also makes the transition harder. Overall, the emergence of the BEE policy did help South Africa transition from chaos to relative stability in the short term. But in the long run, this is not a change that suits South Africa's economic shape. Since then, the government has introduced other policies to try to stimulate the South African economy. This is the BBBEE policy that this review will focus on next

\subsection{Research Review on Improvement}

According to Michael and John argued in the article Poverty, Inequality and Unemployment in South Africa: Context, Issues and the Way Forward, over the past few decades, inequality and poverty have been growing in many developing countries, such as apartheid-era South Africa. It is crucial to find practical and innovative solutions that are conceptual and guide policy and implementation [32]. Having experienced the "BBE" policy, the South African government has a more comprehensive understanding of the reality. They realized that they should focus on the economic or political aspects and the importance of complementing and improving legislation. 
As discussed in this review on economic change in South Africa, South Africa's economy has become much more internationally integrated since the end of apartheid. One major positive change is the economic upturn in the rest of Africa, which is now considered one of the fastestgrowing regions in the world [33]. For example, the " $\mathrm{B}-$ BBEE" policy (Broad-Based Black Economic Empowerment) introduced in 2003 is the management and improvement of the previous version. This policy helped blacks consolidate their rights through clearer laws and regulations and further harmonized the inequities left by segregation. Of course, many more policies made a huge contribution to South Africa's economic development, but that's something to look at later.

\section{CONCLUSION}

The author mainly summarizes the views of different authors on the background, measures and impacts of BEE policy. First of all, there are few studies on black economic revitalization policies, and scholars mainly believe that BEE policy is put forward to meet political and economic development needs. In the process of South Africa's development, the development of BEE policy is mainly divided into two stages, from 1994 to 2000 , which is the early stage of BEE policy development. It is committed to solving the problem of equality for black people. After 2000, the second stage of the BBBEE policy improved the policy in the form of laws and solved the problems arising in the past. Most scholars believe that the BEE policy has contributed to improving South Africa's economy and promoting equality. But South Africa still faces serious challenges in terms of inequality, security, brain drain and unemployment. The government should introduce further policies to change the current situation.

This review intends to proceed from three aspects to discuss the deficiencies of the current research stage from an academic perspective. First of all, in terms of research methods, there is not much data to compare the changes in various aspects after implementing the "BEE" policy or even the "B-BBEE" policy in South Africa. Although, South Africa's economy and politics have made obvious progress due to these reforms. They are all based on empirical ideas. In actual academic articles, there are not many tables and figures to prove it forcefully. The lack of convincing academic articles due to the lack of data is a fatal shortcoming, which should be supplemented and improved.

The second aspect is about the neglect of other perspectives. In a review, it's easy to focus too much on one key point and lose focus on other areas. Overall, this review focuses most of the length on the key point of "Change of Economic policy in South Africa", and many branches born from this, which may lead to repetitions and restatements of the content, which is not good news for readers. Therefore, this review can focus on the changes and impacts brought by the policy changes in South Africa and make some responses to the evolution and future trends of this policy.

The last thing to think about is the matching degree of the content in the review. As an academic article, the professionalism of review must be guaranteed first. In this review, consideration should be given to whether the existence of some sections might not match the key points. Whether the words in the introductory part are too long or the general description of the point of view reduces the focus on the central point so that readers lose interest in the article. For example, this review focuses on the impact of economic policy changes in South Africa, so can the description of the early social background of South Africa be shorted to achieve a brief reading mode?

Although there are many contributing factors, scholars mainly start from the political and economic aspects. BEE policy plays an important role in South Africa's development, whether from the unfair political oppression or the economic restriction.

At present, the policy on the revitalization of the Black people in South Africa mainly focuses on qualitative analysis rather than quantitative analysis. Objective data and experiments should be used to prove the rationality and shortcomings of this policy. Through data, it reflects the existence of some realities, further explores the quality of a series of impacts brought about by the implementation of policies, and draws specific data to describe the areas that need to be adjusted in future policies. This paper summarizes the background, implementation and impact of the policy on the economic revitalization of the Black people in South Africa. It summarizes and sorts out the relevant literature on the policy to provide a reference for future researchers, save time for them, and make their research process more efficient.

\section{REFERENCES}

[1] Yao G.M., (2014). 'Achievements and challenges in South Africa's economic development', journal of Xuehai,2014(3), pp34-37

[2] Giliomee, H., 2003. The Making of the Apartheid Plan, 1929-1948*. Journal of Southern African Studies, 29(2), pp.373-385.

[3] Bowmanslaw.com. 2021. [online] Available at: $<$ https://www.bowmanslaw.com/wpcontent/uploads/2020/10/B-BBEE-Guide-121.10.2020.V2.pdf> [Accessed 3 September 2021].

[4] Swastika, J., Renitha, R. and K, R., 2013. Corporate responsibility for socio-economic transformation: A focus on broad-based black economic empowerment and its implementation in South 
Africa. African Journal of Business Management, 5(20), pp.8224-8234.

[5] Ponte, S., Roberts, S. and van Sittert, L., 2007. 'Black Economic Empowerment', Business and the State in South Africa. Development and Change, 38(5), pp.933-955.

[6] Tangri, R. and Southall, R., 2008. The Politics of Black Economic Empowerment in South Africa. Journal of Southern African Studies, 34(3), pp.699-716.

[7] African National Congress (ANC) (1994) The Reconstruction and Development Programme: A Policy Framework. Johannesburg: Umanyano Publications.

[8] Kleynhans, E.P.J. \& Kruger, M.C., 2014, 'Effect of Black Economic Empowerment on profit and competitiveness of firms in South Africa', Acta Commercii 14(1), Art. \#200, 10 pages. http://dx.doi.org/10.4102/ac.v14i1.200

[9] Ponte, S., Roberts, S., \& van Sittert, L. (2007). 'Black Economic Empowerment': Business and the State in South Africa. Development and Change, 38(5), 933$955 . \quad$ https://doi.org/10.1111/j.14677660.2007.00440.x

[10] Acemoglu, D., Gelb, S. \& Robinson J.A. 2007, Black Economic Empowerment and Economic Performance in South Africa, viewed 06 April 2014, from

http://www.npc.gov.za/MediaLib/Downloads/Hom e/Tabs/Diagnostic/Economy2/Black\%20Economic $\% 20$ Empowerment $\% 20$ and\%20economic\%20perfo rmance $\% 20$ in $\% 20$ South\%20Africa.pdf

[11] South Africa, 1998, Employment Equity Act, 55 of 1998, Government Printers, Pretoria

[12] Republic of South Africa 1998. Skills Development Act, Act 97 of 1998. Pretoria: Government Print.

[13] Republic of South Africa: 2000. Preferential Procurement Act, Act 5 of 2000. Pretoria: Government Print.

[14] HuangYupei.(2016).A Study of South Africa's Black Economic Empowerment During Mandela Period(05),112-119+127. doi:CNKI:SUN:SHXZ.0.2016-05-012.

[15] Sharma, R. "The liberation dividend". Oxford Companion to the Economics of South Africa.

[16] Hirsch, A. (2005) Season of Hope: Economic Reform under Mandela and Mbeki. Scottsville, South Africa: University of KwaZulu-Natal Press.

[17] Ponte, S., Roberts, S., \& van Sittert, L. (2007). 'Black Economic Empowerment': Business and the
State in South Africa. Development and Change, 38(5), 933-955. https://doi.org/10.1111/j.14677660.2007.00440.x

[18] Republic of South Africa (2000)' Charter for the South African Petroleum and Liquid

Fuels Industry on Empowering Historically Disadvantaged South Africans in the

Petroleum and Liquid Fuels Industry'. Pretoria: Government Printer.

[19] Republic of South Africa (2002) 'Broad-Based Socio-Economic Empowerment Charter for the South African Mining Sector'. Pretoria: Government Printer.

[20] Burger, R. \& Jafta, R., 2010, 'Affirmative action in South Africa: An empirical assessment of the impact on labour market outcomes', CRISE Working Paper No. 76, March, viewed 05 April 2014,

from http://r4d.dfid.gov.uk/pdf/outputs/inequality/workin gpaper76.pdf

[21] L. P. Bogopane (2013) Evaluation of Black Economic Empowerment (BEE) Policy Implementation in the Ngaka Modiri Molema District, North West Province, South Africa,Journal of Social Sciences, 34:3, 277-288, DOI: 10.1080/09718923.2013.11893139

[22] South Africa, 2007, Codes of Good Practice, in Government Gazette No. 29570, Government Printers, Pretoria.

[23] Burger, R. \& Jafta, R., 2010, 'Affirmative action in South Africa: An empirical assessment of the impact on labour market outcomes', CRISE Working Paper No. 76, March, viewed 05 April 2014, from http://r4d.dfid.gov.uk/pdf/outputs/inequality/workin gpaper76.pdf

[24] Kruger, L.P..(2011).The impact of black economic empowerment (BEE) on South African businesses : focusing on ten dimensions of business performance. Southern African Business Review(3), doi:

[25] Kruger, L.P..(2011).The impact of black economic empowerment (BEE) on South African businesses : focusing on ten dimensions of business performance. Southern African Business Review(3), doi:

[26] Tucker, C., 2003, Summary of black economic empowerment in South Africa, Bowman

Gilfillan, viewed -5 April 2014, from http://www.bowman.co.za/News-Blog/Blog/

\section{SUMMARY-OF-BLACK-ECONOMIC- EMPOWERMENT-IN-SOUTH-AFRICA}


[27] Cooper, F. 2007. Inequality in South Africa during and since Apartheid. Journal of Southern African Studies. 33(2),pp.455-457.

[28] Bhorat, H., Ncube, M., Kanbur, R. and Hirsch, A. 2014. Economic policy in South Africa-past, present and future. Oxford: Oxford University Press.

[29] Fan, X. 2016. A brief analysis of apartheid in South Africa. Historical research., pp.143-144.

[30] Ozler, B. 2007. Not Separate, Not Equal: Poverty and Inequality in Post-apartheid South Africa. Economic Development and Cultural Change. 55(3), pp.487-529.

[31] Feinstein, C.H. 2005. An Economic History of South Africa: Conquest, Discrimination, and Development. Cambridge University Press.

[32] Chibba, M. and Luiz, J.J.M. 2011. Poverty, Inequality and Unemployment in South Africa: Context, Issues and the Way Forward. Economic Papers A journal of applied economics and policy. 30(3), pp.307-315.

[33] Freund, B. 2007. South Africa: The End of Apartheid $\&$ the Emergence of the 'BEE Elite'. Review of African Political Economy. 34(114), pp.661-678. 